\title{
Akl-ı Selimden Zevk-i Selime: "Edebiyat" Kelimesinin İlk Kullanımı ve Anlamı
}

\author{
Berat Açı*
}

\begin{abstract}
Öz: "Edebiyat" kelimesinin Arapça "edeb” kelimesinden türetildiği görüşü, akademide yaygınlık kazanmıştır. Bu kelimenin ne zamandan beri kullanıldığına dair tartışmalar olmakla birlikte, kelimenin on dokuzuncu yüzyılın ikinci yarııından itibaren kullanılmaya başladığı genel kabule mazhar olmuş bir iddiadır. Mevcut literatür, kelimenin Fransızca "litterature"ü karşılamak üzere 1880'lerde tedavüle girdiği konusunda hemfikirdir. Bu genel kabullere rağmen yapmış olduğumuz araştırmalar ve yeni bulgular neticesinde hem Arap dünyasında hem de Osmanlı dünyasında kelimenin çok daha evvelki yüzyıllarda kullanılmış olduğunu tespit ettik. Arapçada on birinci yüzyılda, Osmanlı topraklarındaysa on altıncı yüzyılda kelimenin iki farklı eserde yer aldığına şahit olmaktayız. Bu eserlerin ilki, 1038 yılında vefat etmiş olduğunu bildiğimiz meşhur Arap dil ve belagat âlimi Sealibî'nin Yetîmetü'd-dehr fî mehâsini ehli'l-asr adlı şair ve edipler tezkiresi mahiyetindeki eseriyken ikincisi, el-Kostantinî́nin 1529 tarihinde İbrahim Paşa'ya sunduğu, siyasetnâme türündeki Letâifü'l-efkâr ve Kâşifü'l-esrâr adlı eserdir. Dolayısıyla biri Arap dünyasından diğeri Osmanlı ülkesinden iki örnek bizi açık bir şekilde zorunlu kıldığı için kelimenin ilk kullanımına dair görüşlerimizin yeniden gözden geçirilmesinde fayda mülahaza ediyoruz.
\end{abstract}

Anahtar Kelimeler: Edebiyat, edeb, belagat, el-Kostantinî, Sealibî

Abstract: The idea that the word "literature" (edebiyat) was derived from the Arabic word of "edeb" gained a prevalence in academy. Despite debates about how long this word has been used, it is a widely accepted claim that it started to be used as of the second half of the 19th century. Existing literature agrees that the word came into use in the 1880s in order to meet the French word of "litterature." Despite this general consent, we found as a result of our research and new findings that the word was used both in the Ottoman and Arab world in much earlier centuries. We found that the word was used in two different works in Arab and Ottoman territories in the 11th and 16th centuries, respectively. The first one is a collection of biographies of poets and litterateurs titled Yatimat al-dahr fi mahasin ahl al-asr, which was written by famous Arabic scholar specialized in language and rhetoric Abu Mansur Al-Tha'alibi who died in 1038. The second one is a political treatise titled "Lataif al-afkar va Kashif al-asrar, which al-Kostantinî presented to Ibrahim Pasha in 1529. So, as two instances from the Arab and Ottoman word clearly urge us, we argue it is beneficial to revise our ideas about the first use of the word.

Keywords: Literature, adab, eloquence, al-Kostantinî, Sealibî

* Yrd. Doç. Dr., İstanbul Şehir Üniversitesi, Türk Dili ve Edebiyatı Bölümü.

E-posta: beratacil@sehir.edu.tr. Adres: İstanbul Şehir Üniversitesi Batı Kampusü, Oymacı Sok. No: 15, Altunizade Mah. Üsküdar/İstanbul.

DOI: dx.doi.org/10.12658/human.society.5.10.M0161

İnsan ve Toplum, 5 (10), 2016 


\section{Giriş}

Herhangi bir olgunun ortaya çıktığı ilk anı tespit etmek her zaman heyecan verici, merak uyandırıcı bir uğraş olmuştur. Edebiyat olgusu ve kavramı da bu bağlamda ele alınabilir. Edebiyat olgusunun ne zaman ortaya çıktığını araştırmak, insanlıkla eş zamanlı bir meseleyi irdelemek anlamına geldiğinden bugünkü bilgilerimize göre tespiti neredeyse imkânsız, beyhude bir çaba anlamına gelebilir. Öte yandan edebiyat kelimesinin ilk defa ne zaman kullanıldığını belirlemek hem imkân dâhilinde hem de akademik anlamda oldukça önemli sonuçlar doğurabilecek, faydalı bir araştırma konusudur. Bu itibarla, bu makalede edebiyat kelimesinin ilk defa ne zaman kullanıldığına dair yeni bir tespitimizi ilim dünyasına sunmaya çalışacağız. Öncelikle edebiyatla ilgili şu ana kadar yapılmış çalışmalardan hareketle kelimenin ilk kullanımına dair yaklaşımları tartışacağız. Daha sonra edebiyat kelimesinin ilk defa ne zaman kullanıldığına dair tespitimizi sunup edebiyatın o zaman ne anlama geldiğine değineceğiz.

\section{Edebiyat Kelimesinin IIlk Kullanımına Dair Mevcut Literatür}

Edebiyat kelimesinin ilk defa Tanzimat döneminde kullanıldığına dair yaygın bir kanaat vardır. Bunun hem nedenlerinden biri hem de göstergesi olarak Orhan Okay'ın İslam Ansiklopedisi'ndeki "Edebiyat" maddesi gösterilebilir. Okay'a göre edebiyat, "[k]elime ve kavram olarak Türkçede Tanzimat'tan sonra kullanılmaya başlanmış veya bu tarihten sonra gittikçe yaygınlaşmıştır." (1994, 395) Kelimenin bu tarihlerde türetildiğini tahmin eden Okay'a göre edebiyatın kullanımının yaygınlaşması bir tercüme ihtiyacından kaynaklanmış olabilir. "1860'lardan sonra yaygınlaşan edebiyat kelimesi, bu yıllarda çeşitli bilim alanları için Fransızcadan tercüme yoluyla Osmanlıcaya kazandırılan terimlerle (lisâniyat, arziyat, rûhiyat vb.) aynı yapıda olduğunu düşündürmektedir... O zamana kadar Arapçada bu anlamda kullanılmış böyle bir türevin bulunmaması da bu tahmini doğrulamaktadır." (1994, 395) Burada dikkati çeken ve makalemizin asıl ilgilendiği nokta, Arapçada bu anlamda türetilmiş bir kelimenin daha önce kullanılmamış olduğunun iddia edilmesidir. Bu makalenin konusu olmamakla beraber Arap dilince "edebiyat" kelimesinin çok daha önceki yüzyıllarda kullanılmış olduğuna dair en azından bir delile ulaştığımızı geçerken nakletmekte fayda mülahaza ediyoruz. 11. yüzyıl âlimlerinden Sealibî'nin (ö. 1038) Yetîmetü'd-dehr fî mehâsini ehli'l-asr adlı bir nevi şair ve edipler tezkiresi olan eserinde edebiyat kelimesi açık bir şekilde, "ve lehu mine'l-edebiyyât" (Sealibî, t.y., vr. 479a) şeklinde alt başlık olarak kullanılmıştır.2

Edebiyat ve belagatle ilgili öncü çalışmalara imza atmış olan Kaya Bilgegil, edebiyat kelimesinin Arapçanın çok eski zamanlarından, "edeb" kökünden geldiğini, on dokuzuncu yüzyıldaki anlamını daha sonra kazandığını düşünmektedir.

Çok eski çağlarda "davet" mânâsına gelen "edb"; İlâmlıktan bir yüz yıl önce, zariflik ve ahlâkla ilgili edeb kelimesini doğurmuştu. Bu mânâ, Emevîler'in son, Abbasîler'in ilk yıllarına kadar sürdü. Emevî devletinin yıkılmasına yakın yıllarda, halîfeler çocuklarının yetiştirilmesi için "müeddib" seçmişlerdir, bunun bir gelenek hâlinde ilk Abbasî

2 Bu makalede kelimenin Osmanlı sahasındaki serencamılla ilgilendiğimiz için, bu önemli bulguyu irdelemeyi başka bir çalışmaya bırakıyoruz. 
halîfeleriyle onların vezirlerine de geçtiğini biliyoruz. Müeddibler şiir, târîh, din bilgisi öğretiyorlardı. ... Nahiv, tasrif, arûz, belâgat usulü gibi dile hizmet edecek eserlerin te'lîfine girişildikten sonra, bunlar da "edeb" sözü ile ifâde edildiler. Kelime, bu kavram şümûlünü geçen yüzyıla kadar muhafaza etti. $(1989$, s. 2)

On dokuzuncu yüzyılda "edeb" kökünden türetildiği düşünülen edebiyat kelimesinin ${ }^{3}$ o dönemde ne anlamda kullanıldığı da konumuz açısından önem arz etmektedir. Bu sorunun cevabı Okay'ın söz konusu maddesinde şöyle verilmektedir: "Edebiyat duygu, düşünce ve hayallerin okuyucuda heyecan, hayranlık ve estetik zevk uyandıracak şekilde sözle ifade edilmesi sanatıdır." (1994, s. 396) Bugün de büyük ölçüde geçerliliğini koruyan bu tanımın on dokuzuncu yüzyıldan sonraki Batı kültürü ve edebiyatlarıyla etkileşim neticesinde meydana çıktığı anlaşıımaktadır. Söz konusu tanımın önceki yüzyıllarda da geçerli olup olmadığı sorusunu ileride tartışacağız.

Edebiyat kelimesinin 1860'lardan sonra Fransızca "litterature"4 kelimesi karşıı̆ı̆ı kullanılmaya başlandığı görüşü başka araştırmacılarca da dile getirilmektedir. Kâzım Yetiş bu konuda çokça çalışma yürütmüş ve yukarıdaki görüşü savunan araştırmacılardan biridir: "Kelimenin Namık Kemâl'de yaygın kullanılışa kavuştuğunu görüyoruz. Onun 'edebiyat' ve 'Osmanlı edebiyatı' hakkındaki düşüncelerini ihtiva eden ilk yazısı 'Lisân-ı Osmanî'nin Edebiyatı Hakkında Mülâhazatı Şâmildir' başlığını taşır. Burada, 'edebiyat' sözü müstakil bir ıstılah olarak devamlı surette geçer." (1996, s. 144) Kâzım Yetiş, Recâzizâde Mahmud Ekrem Bey'in 1886 'da yazdığı bir yazısında edebiyat sözünün "beş on seneden beri erbâb-ı kalem arasında zebânzed olmuş" olduğunu ifade ettiğini ve Kemal Paşazâze Said Bey'in de 1882'deki bir yazısında daha önce "şiir ve inşâ" tabirini kullandığını belirttiğini aktarmaktadır (1996, s. 144). Başka bir bağlamda Said Bey'in durumunu tahlil eden Fatih Altuğ, "Dikkat edilirse Kemal Paşazâde Said, bir yandan şiir ve inşa tabirini kullanacağını söylerken diğer yandan edebiyatın artık bu tabirin yerine geçtiğini de kabul etmektedir" $(2007$, s. 20) diyerek yeni bir durumla karşılaşan Osmanlı́nın en azından ilk karşılaşma anında eski ve yeniyi bir arada kullanmayı tercih ettiğini göstermektedir. Recâizâde gibi edebiyatı hem şekillendiren hem de yakından takip eden bir aydının tespitini doğru kabul edersek, kelimenin Orhan Okay'dan yukarıda alıntıladığımız anlamıyla, yani bir ıstılah olarak kullanılmaya başlaması aslında 1880 civarıdır.

Bundan önce edebiyat kelimesinin ıstılah olarak değil de kelime olarak kullanımına dair 1872 tarihini kesin bir tarih olarak vermek mümkündür çünkü Andreas Tietze'ye göre edebiyat kelimesi yeni anlamılla ilk defa E. Misailidis'in Temâşa-i Dünya ve Cefâkar u Cefakeşadlı eserinde kullanılmıştır. Nitekim Tietze'nin aktardığına göre Misailidis'in cümlesi şöyledir: "Hükümdârân böyle edebiyât ve ahlâkiyeti ihlâl edici sebepleri def' u izâle etseler pek hoş olur idi." (2002, s. 688) Tietze'ye göre bu cümleden yola çıkarak edebiyat kelimesinin anlamı "okumuşluk, iyi terbiye görmüş kimsenin hâli"dir (Misailidis, 1986 [1872], s. 147). Böylece reyen "literature" kelimesidir. Bu kelimenin kökeni Latince olup İngilizcede ilk defa on dördüncü yüzyılın sonlarında "öğrenme, yazı, dil bilgisi" anlamlarında kullanılmıştır. "Edebî üretim ve edebiyat eseri" anlamını 1779 'da kazanmışken "bir dönemin veya bir kişinin yazılarının toplamı" anlamını ise 1812'de kazanmıştır. Bkz. http://www.etymonline.com/index.php?allowed_in_frame=0\&search=literature Erişim Tarihi: 15.01.2016. 
Tietze de bugünkü anlamıyla edebiyat kelimesinin on dokuzuncu yüzyııın ikinci yarııından itibaren kullanılmaya başladığını hem söylemiş hem de desteklemiş olur.

Namık Kemal'in Recaizade Mahmut Ekrem'e gönderdiği bir mektuptan aldığımız şu cümleler edebiyat kelimesinin $1880^{\prime}$ deki anlamın daha sarih bir şekilde ortaya koymaktadır:

[F]akat Şinâsî'nin "...Haslet-âmûz-ı edeb..." kâ'idesi müsellem olunca, istişhâd için edebiyat âlemine dâhil olamaz; fakat edebiyât sözüne nisbet pek ziyâde vâsi' olan literature aksâmında dâhildir. Lisânın bu hâllerine bakılınca, literature'ü insanın âdetâ kudemâ veyâ Ziya Paşa gibi Şiir ve İnşâ ile tercüme edeceği geliyor. Şiir ve İnşâ yerine, aynen tercüme edip de kitâbet desek, lâfzdan bizim isti'mâlimizce hem şiir sâkıt oluyor, hem de kâtib efendilerimizin yazdıkları "niyâzım bâbında" arz-ı hâlleri kitâbet veyâ literature sınıfına iltihâk ediyor; öyle değil mi? (Karakoç, 2012, s. 16)

Görülüyor ki 1880'de her ne kadar edebiyat kelimesi kullanımda olsa da kavramın anlamı ve neyin yerine kullanılması gerektiği konusunda bir ittifak henüz oluşmuş değildir. Bununla birlikte edebiyat kelimesiyle Fransızca "litterature" kelimesi arasında bir ilişki kurulduğu açıktır. Fransızca kelimenin tam karşıı̆ı "kitâbet"tir fakat şiir de dışarıda bırakılmak istenmemektedir. Dolayısıyla bunlar Ziya Paşa'nın Şiir ve İnşa tercihinden daha kullanışlı değillerdir. Öyle anlaşılıyor ki bu kararsızlık Fransızca kelimenin olduğu gibi kullanılmasına ve sonunda edebiyatın yerleşmesine sebep olmuştur.

Ziya Paşa'nın şiir ve inşa isimlendirmesi eskilerin nazım-nesir ayrımını akla getirdiği için Osmanlı dönemi klasik Türk edebiyatına dâhil edilebilecek hemen hemen tüm edebî ürünleri içine alan şümullü bir tanımlama addedilebilir. Şiir dendiğinde başta gazel olmak üzere, kaside, mesnevi, rubai, müstezâd gibi tüm nazım biçimleri ve tevhit, na't, münacat, medhiye, bahariyye, hicviye, mersiye, sakinâme, surnâme gibi nazım türleri akla gelebilmekteydi. Benzer şekilde nesir dendiğinde de tezkireler, münşeatlar, seyahatnâmeler, siyerler, gazavatnâmeler gibi türler hemen akla gelmekteydi. Dolayısıyla şiir ve inşa vakıaya mutabık olmalarının yanı sıra kullanım rahatı̆̆ı da sağlıyorlardı. Edebiyat, kitabet, lisaniyat, kudemâ gibi adlandırmalardaki asıl zorluk tam da burada yatmaktadır. Dönemin edebiyatçı ve aydınları, bütün eserleri içine alabilecek isim arayışındaydılar. Edebiyat kelimesinin geç yerleşmesinin ve gelenekle bağından dolayı da zihnen daha kolay kabul edilmesinin sebebi, kelimenin hem yeni hem de farklı olması olsa gerek.

\section{Edebiyat Kelimesin İlk Kullanımı ve Anlamı}

Şimdiki bilgilerimize göre edebiyat kelimesinin ilk kullanımı ve anlamına dair bu kısacık değerlendirmeden sonra bu makalenin asıl yazılma amacına geçip (ulaşabildiğimiz kadarıyla) kelimenin gerçekte ilk defa ne zaman kullanılmış olduğuna dair tespitimizi tartışmaya başlayabiliriz.

Edebiyat kelimesinin içinde ilk defa kullanıldığını düşündüğümüz eser Osmanlı döneminde yazılmış Hüseyin b. Hasan el-Kostantinî'ye ait olan Letâifü'l-efkâr ve Kâşifü'l-esrâr adlı Arapça eserdir. ${ }^{5}$ El-Kostantinî, Kanûnî Sultan Süleyman dönemi kadılarından biri olup eserini 1523-

5 Bu eserden ilk söz eden kişi Hüseyin Yılmaz'dır. Bkz. Yılmaz 2005: 68-70. Yılmaz eserin müellifini Hüseyin b. Hasan es-Semerkandî olarak tespit etmiştir. Özgür Kavak da aynı kanaati paylaşmış (Kavak 2012: s. 95-120) 
1526 yılları arasında vezir-i azam olan İbrahim Paşa'ya ithaf etmiştir. Letâifü'l-efkâr ve Kâşifü'lesrâr, ${ }^{6}$ ansiklopedik tarzda kaleme alınmış bir eserdir. Eserin bu makale, edebiyat ilmi ve tarihi açısından önemi, beş bölümünden birinin edebiyat başlı̆̆ını taşıyor olmasıdır. "Beş bölüm ve altmış beş fasıldan oluşan kitabın bölümleri a) "Siyaset," b) "Hz. Adem'den 935 yılına kadar Haremeyn-i Şerîfeyn'deki halîfelerin tarihi," c) "Edebiyyât," d) "Övülen ve yerilen huylar" ile e) "Mahlûkâtın acâyibine ve mevcûdâtın garâyibine dair" başlıklarını taşımaktadır." (Kavak, 2012, s. 97)

Eserin telif tarihinin 935/1529 olduğu tahmin edilmektedir (Kavak, 2012, s. 96). Söz konusu eserin üç nüshası mevcut olup Özgür Kavak'ın incelemiş olduğu nüsha en eski tarihli (1031/1622) nüshadır. ' Ayrıca diğer iki nüshada edebiyat bölümü yer almamaktadır (Kavak, 2012, s. 95). Elimizdeki nüshadan sonra istinsah edilmelerine rağmen ikinci ve üçüncü nüshada edebiyatla ilgili bölümün yer almaması merakı mucip olsa da şu anda bu soruya yeterli bir cevap verebilecek malumata sahip değiliz. Kavak'a göre eserin İbrahim Paşa'ya sunulması teamüllere aykırı olup amaç, Osmanlıların âlem tasavvurunu bütünlüklü bir şekilde sunmaktır. Bundan dolayı eser, ansiklopedik bir tarzda telif edilmiştir (Kavak, 2012, s. 98). Hüseyin Yılmaz, Paşa bu göreve erken denebilecek bir yaşta, yirmi dokuz yaşında vezir-i azamlık pozisyonuna geldiği için müellifin eserini İbrahim Paşa'yı "yönetim, ahlak, tarih, edebiyat ve dinî gelenekler" konusunda eğitmek amacıyla ansiklopedik bir biçimde yazdığını iddia etmektedir (Yılmaz, 2005, s. 68).

Eserin bizi daha fazla ilgilendiren yönüne, yani edebiyatı nasıl tanımladığı ve ele aldığı meselesine cevap bulabilmek için söz konusu bölümü detaylı bir şekilde tahlil etmemiz gerekecektir. Edebiyyât üst başlı̆ını taşıyan kitabın mezkûr üçüncü bölümü kendi içinde (1) edebiyyâta ve akl-ı selîmin ve üstün zihinlerin medhine dair, (2) zekâya dair ve (3) edebî nüktelere dair olmak üzere üç fasıldan oluşmaktadır. Makalenin bu kısmında her bir bölümü ayrı ayrı ele alıp sonuçta bütünlüklü bir resme varmaya çalışacağız.

Edebiyat bölümünün ilk faslı "edebiyyâta ve akl-ı selîmin ve üstün zihinlerin medhine dair" başlığını taşımaktadır. Dolayısıyla, en azından ilk bakışta; "edebiyyât", "akl-ı selîm" ve "üstün zihinler"den tefrik edilmiş şekilde ele alınmış görünmektedir.

Illk faslın başlığından da anlaşıldığı gibi edebiyat, akl-ı selîm yani çabuk anlama kabiliyetiyle bir arada kullanmıştır. Anlaşıldığına göre yazarın zihninde edebiyat, "beyân" ile bir arada düşünülmüştür çünkü edebiyatı açıklamak için yazarın yöneldiği ilk kavram, belki de edebiyatın ilk rüknü, beyan olarak tezahür etmiştir. Bilindiği gibi beyan, klasik belagat ilminin ma'ânî ve bedî́ ile birlikte üç kısmından birisidir (Hâşîmî, 1971, s. 153-215; el-Cârim, Mustafâ Emîn, 1981, s. 19-127). “Edebiyat terimi olarak beyân, mânayı ifadede lafzı açıklığa kavuş-

fakat daha sonraki bir konuşmasında müellifin nisbesinin/isminin el-Kostantinî olması gerektiğini dile getirmiştir (Kavak 2014). Eseri tercümesiyle beraber yayıma hazırlamakta olan Özgür Kavak'a, hem eserden bizi haberdar ettiği hem de ilgili bölümü kullanmamıza izin verdiği için teşekkür ederim.

7 Bilindiği gibi yazmalarda başlıklar müstensih tarafından konabilmektedir. Dolayısıyla elimizdeki eserde de benzer bir durumun vaki olduğu düşünülebilir. Durum böyleyse eğer, yani edebiyatla ilgili bölümün başı̆̆ı sonradan, müstensih tarafından eklenmişse, edebiyat kelimesinin ilk kullanımı için 1529 tarihini 1622 tarihine çekmemiz gerekecektir. Bu varsayımı doğru kabul ettiğimizde bile edebiyat kelimesinin ilk defa bu eserde kullanılmış olduğu iddiası geçerliliğini korumaya devam edecektir. 
turmak için gereken melekeyi kazandıran, duygu ve düşünceleri değişik yollarla ifade etme usul ve kaidelerini inceleyen ilim demektir." (Hacımüftüoğlu, 1992, s. 22) Müellifin Kur'ân-ı Kerim'in elli beşinci suresi olan Rahman Suresinden iktibas ettiği ilk dört ayette geçen "beyân" kelimesi, tevriyeli kullanılmış olup Kur'ân-ı Kerim'deki anlamlarından biri "ifade etmek", diğeri de yukarıda aktardığımız belagatteki anlamıdır. Dolayısıyla, Allah'ın Kur'ân'ı öğretmesi, insanı yaratması ve beyanı öğretmesi onun rahmetindendir sonucuna varmak mümkün görünmektedir.

Müellifin Allah'ın kelamını iktibas ettikten sonra peygamberden delil getirmesi; geleneksel söylem ve kitabet içinde kendine muhkem bir yer edinmiş olan besmele, hamdele, salvele silsilesiyle yetişmiş bir müelliften beklenebilecek bir sıralamadır. Nitekim hemen sonrasında Peygamber efendimizin beyanın en azından bir kısmının sihirli olduğunu dile getirmiş olduğu aktarılır. Daha sonra sırasıyla büyük Arap nesir yazarlarından Câhiz (ö. 869) ${ }^{8}$ ve İbn Muarrâ'nın (ö. ?) beyana dair söyledikleri nakledilmiştir.

El-Kostantinî, beyanla ilgili örneklerine devam ederken Hişâm b. Urve'nin ${ }^{9}$ (ö. 763) fesahat ve beyâna dair şaşkınlığını belirten cümlesini de alıntılamıştır: "Insanların iş edindikleri hususlar arasında bana en ilginç geleni fesahat ve beyandır." (t.y., vr. 59a) Burada yeni olan müellifin beyânın yanına fesahati de eklemiş olmasıdır. Fesahat da beyân gibi bir belagat terimidir. Beyân daha çok mana veya ifadeyle ilgiliyken fesahat sözle ilgilidir. Belagat terimi olarak "sözün kusursuz ve açık olması" (Çuhadar, 1995, s. 423) anlamına gelmektedir. Dolayısıyla beyân ve fesahat ile birlikte konuşmanın iki önemli unsuru olan söz ve manaya/ ifadeye ait unsurlar zikredilmiş bulunmaktadır. Netice olarak konuşmanın bütününe dair hususlardan bahis açılmış olmaktadır. Nitekim sonraki iki alıntı da "nutk" ve "lisân" ile ilgilidir. Nutk sayesinde peygamberler insanları doğru yola davet edebilmişlerdir çünkü insan, "hayvan-ı nâtıka"dır. ${ }^{10}$ Bu da onu "lisân" sahibi yapmaktadır çünkü lisan için sesleri çıkarmak yetmez, aynı zamanda düşünme yeteneğine sahip olmak gerekir. Bu özellikleri de insanı, hayvandan ayıran, onu İlahî hitaba muhatap kılan özellikleridir.

Bu kısımda insanın konuşabilme ve konuşmaya muhatap olabilme özelliklerinin öne çıkarıldığı görülmektedir. Bunu temin etmek isteyen müellif; belagat, beyan, fesahat, nutk ve lisan gibi unsurlara dair hususları zikrettikten sonra edebiyatla ilgili ikili bir taksim yapmaktadır. Fakat burada kullandığı kelime "edeb"dir ki Arap dilinde bu kelime, günümüze kadar edebiyat anlamında kullanılagelmiştir. Dolayısıyla müellifin zihninde edeb ve edebiyyât kelimelerinin çok net ayrımlarla tefrik edilmemiş olduğu tespitini yapmak yerinde olacaktır.

Müellife göre edeb, nefsî ve kesbî olmak üzere ikiye ayrılmaktadır. Nefsî olan Allah’ın tevfikinden olduğu için de Allah onu istediğine verir. Bu tanıma göre nefsî edeb, vehbî ve kesbî şair ${ }^{11}$ ayrımına benzemektedir. Vehb kelimesi, buradaki nefs kelimesine benzer şekilde kul-

8 Câhız hakkında geniş bilgi için bkz. Şeşen 1993 s. 20-24.

9 Tâbiîlerden bir önemli bir muhaddis. Bkz. Kandemir 1998: 155-156.

10 Aristo'nun mantığın en temel argümanlarından biri olmuş cümlelerinden biridir. İnsanı tanımlaya çalışırken onu hayvandan ayırmak ihtiyacı doğmuş; insanın hayvandan ayrılan en temel özelliği olarak da "nâtık" yani düşünebilme ve konuşabilme özelliği vurgulanmıştır.

11 Bu ayrım için Bkz. Latifi 2000:485. 
lanılmaktadır. Hem Latifi'́nin vehbî şairin karşısına yerleştirdiği şair hem de el-Kostantinî́nin nefsî edeb'in karşısına yerleştirdiği edebiyatçı kesbî şiir/edep sahibidir. Kesb, bilindiği gibi kişinin çalışması sonucu elde ettiğidir. Osmanlı şiirinde vehb'in üstün tutulması gibi burada da onun muadili nefs, kesb'e üstün tutulmuştur. Arapların lügati ve hikmet, kesbî edeb cinsinden addedilmiştir çünkü bu ikisinin elde edilmesi için ciddi çalışma gerekmektedir (el-Kostantinî, t.y., vr. 59a).

Yukarıda dile getirildiği gibi edebiyatın, bir unsuru fesahattir. Fesahat sahibi kişilere yani sözü güzel söyleyenlere göre fazilet, soy-sopla elde edilmez, aksine akıl ve edeble elde edilir. Bunun nedeni bilgi, fazilet, kemal, âdâb, akıl gibi kişinin çalışarak elde edebileceği hasletlerin atalar, soy-sop, cemal, esvap, yakınlar gibi doğuştan gelen, kişiden bağımsız hasletlere nazaran daha kalıcı olmasıdır.

Metinde de belirtildiği gibi kişi, bilgisiyle kişi olur, atalarıyla değil; faziletiyle olur, soy ve sopuyla değil; kemaliyle olur, cemaliyle değil; âdâbıyla olur, esvabıyla değil; aklıyla olur, yakınları ile değil. Nitekim metinde de dile getirildiği gibi "Edeb sahibi kişi, soya ihtiyaç duymaz. Soylular ise edebe muhtaçtırlar." (el-Kostantinî, t.y., vr. 59b) Bundan sonra Peygamber efendimizin Habeşistan kralı Necâşî́ye (ö. 630) gönderdiği mektup, Harunürreşid'in oğlu, Abbasî halifesi Me'mûn'un (ö. 833) bir sözü, bir şiir ve meşhur Sasanî vezir-i azamlarından Büzürcümihr'den bir anekdot, birer belagat örneği olarak aktarılmıştır.

Sonuç olarak bu bölümde akl-ı selim, beyan, fesahat, nutk, lisan, belagat ve edepten oluşan bir silsile dâhilinde edebiyat anlatılmıs olmaktadır. Nihayetinde tüm bu unsurların akılla bağı kurulmuş ve nesep olmasa da akıl ve edebiyatın kişiyi şerefliler arasına katacağı vurgulanmıştır. O hâlde, her ne kadar nefsî edeb Allah vergisi bir haslet olsa da edebiyat akılla elde edilebilen bir özellikliktir sonucuna varılabilir.

İkinci fasıl zekaya ayrılmıştır. Edebiyat, belagat ve akla dair meselelerden sonra zekaya dair unsurlar anlatılmaktadır. Müellif ikinci cümlede meşhur İslam âlimlerinden biri olan Zemahşerî'den (ö. 1144)12 bir alıntı yapmaktadır: "İslam milleti üç şey ile övünürse övünç olarak ona yeter: Siyaset için Ömer b. el-Hattâb, zühd için el-Hasen el-Basrî ve belagat için Câhiz." (el-Konstantinî, t.y., vr. 60a) Bu sıralama kitabın geneli için de mühim olsa gerek zira İbrahim Paşa'ya sunulmuş olan kitap haddizatında bir siyasetname olarak da düşünülebilir. İbrahim Paşa'ya ve elbette okurlara, siyaset için Ömer b. El- Hattâb, zühd konusunda el-Hasen el-Basrî ve belagat vadisinde de Câhiz örnek gösterilmektedir. Bir devlet adamının Hz. Ömer'in siyasetine, Hasan Basrî́nin zühd ağırlıklı tasavvufi görüşüne ve Câhiz'in beliğ dil zevkine sahip olmaya çalışması salık verilmiştir.

Bu bölümde fesahat ve belagatin zekayla ilgisini açı̆̆a çıkaran örneklere yer verilmiştir. Sadece zeki olmak veya sadece fasih sözler söylemek ya da beliğ konuşmak, tek başına kişiyi yüksek bir mertebeye ulaştırmaz; ikisinin bir arada bulunması gerekmektedir.

Edebiyat bölümünün son faslı edebî nüktelere dairdir. Bilindiği gibi nükte kelimesi sözlükte "yazıda, resimde, sözde ve davranışta ince, derin anlam, espri" (Parlatır, 1998, s. 1665) anlamına gelmektedir. Bu nedenle nükte, hem fesahat hem de zeka ile doğrudan ilgilidir. 
Nüktelerdeki incelikleri anlamak için hem kıvrak bir zekaya hem de güçlü bir birikime sahip olmak gerektiği için nükte, aynı zamanda, muhatabın edebiyatla ilişkisini de ölçen bir araç hâlini almaktadır.

Toparlamak gerekirse, edebiyata dair bölüm (1) akl-ı selîm ve üstün zihinler, (2) zekâ ve (3) edebî nükteler olmak üzere üç fasıldan oluşmaktadır. Üçünü birlikte ele aldığımızda akıl ve zekânın ortak malzeme olarak öne çıktığı görülmektedir.

\section{Sonuç}

İçinde yaşadığımız olgulara olduğu kadar günlük yaşamımızda kullandığımız kelime ve kavramlara da alışkanlığın bir neticesi olarak hep varlarmış gibi yaklaşırız. Oysa ki her olgu gibi her kelime ve kavram da doğal olarak belli bir zaman diliminde ortaya çıkarlar. Bunların kiminin tespiti neredeyse imkânsızken kimininki ise nispeten mümkündür. Edebiyat kelimesinin ilk kullanımını tespit etmeye çalışmak ikinci gruba girer. Kelimenin ilk defa ne zaman kullanıldığını tespit etmeye çalışmak imkân dâhilinde olduğu gibi önemlidir de.

Edebiyat kelimesinin on dokuzuncu yüzyılın ikinci yarısında ilk defa kullanılmaya başlandığı akademide yaygın bir görüştür. Bu görüşe göre kelime, on dokuzuncu yüzyılın ikinci yarısında Fransızca "litterature" kelimesini karşılamak üzere, lisâniyat, kitâbiyât kabilinden bir kelime olmak üzere "Şiir ve İnşâ", daha doğrusu eskilerin nazım ve nesir diye tesmiye ettikleri alanı tanımlasın diye türetilmiştir. Zamanla bugünkü anlamını yüklenmiş olan kelimenin kavramsallaşma sürecine dair çalışmalar yapılmış olsa da kelimenin öncesine yönelik ciddi bir eleştirel yeniden ele alışla karşılaşılmamıştır.

On altıncı yüzyılın ilk yarısında yazıldığını bildiğimiz Letâifü'l-efkâr ve Kâşifü'l-esrâr adlı eser bu konudaki fikirlerimizi ciddi anlamda yeniden sorgulamamız gerektiren kimi veriler sunmaktadır. Eser, bir siyasetname gibi yazılmış olup Pargalı İbrahim Paşa'ya 1529 yılında sunulmuştur. Elimizde üç nüshası olan eserin en eski tarihli nüshası 1622 tarihlidir. Bu eserin konumuz açısından ehemmiyeti beş bölümünden birinin edebiyat hakkında olmasıdır. Aşağıya tercümesini verdiğimiz söz konusu bölüm, hem edebiyata yüklediği anlam hem de edebiyat kelimesini çok erken bir tarihte kullanmış olması açısından büyük önem arz etmektedir. Yaptığımız inceleme sonucu bu bölümde edebiyat kelimesinin akl-ı selim, zeka, belagatin beyan ve fesahat kolları, tarihî anekdotlar, ahlak, din ve edebî nüktelerden müteşekkil bir anlama gelecek şekilde kullanıldığını tespit ettik.

Araştırmalarımız neticesinde ulaştığımız fakat bu makale içinde değerlendirmediğimiz bir bulgumuz ise on birinci yüzyıl Arap dili ve belagati âlim ve şairlerinden Sealibî'nin Yetîmetü'd-dehr fî mehâsini ehli'l-asr adlı eserinde de yine bir alt bölüm başlığında edebiyat kelimesinin kullanılmış olduğudur. Her ne kadar burada dil ve nükte anlamları öne çıkıyor gibi görünse de söz konusu metin için de ayrıntılı bir incelemeye ihtiyaç vardır.

Sonuç olarak edebiyat kelimesiyle ilgili tartışma ve araştırma, herhangi bir ilmî meselede nihai sözü söylemenin güçlüğünü ortaya koymaktadır. Burada yaptığımız gibi, bir olgunun veya kelimenin ilk ortaya çıkışına dair ulaşabildiğimiz tarihi belirtmekle iktifa etmek akademik bir zaruret halini almaktadır. 


\section{Metin}

[59a] 3. Bâb: Fasıllardan oluşur. Birinci Fasıl, edebiyyâta ve akl-ı selîm ile üstün zihinlerin medhine dairdir.

Yüce Allah şöyle buyurmuştur: "er-Rahmân Kur'an'ı öğretti, insanı yarattı ve ona beyânı öğretti." Rasulullah (sav) şöyle buyurmuştur: "Kuşku yok ki beyânın bir kısmı vardır ki o sihir[li bir etkiye sahiptir]". Câhiz ise şöyle söylemiştir: "Beyân, mâna bakımından kapalı kalan hususlarda sana keşf olunan tüm her şeyi birleştiren bir isimdir." İbn Muarrâ ise "beyân kalblerin tercümanı ve akılların cilasıdır" demiştir. Hişâm b. Urve ise "İnsanların iş edindikleri hususlar arasında bana en ilginç geleni fesâhat ve beyândır" demiştir. Hükemâ ise şöyle demişlerdir: "Susmak, [aklın] uyku[su]dur, nutk ise yakazadır. Zira Allah Teala enbiyasını nutk sayesinde hüccet lisânı olarak göndermiştir." Halid b. Safvan "lisân olmasaydı insan da olmazdı. Bu durumda sadece şekle bürünmüş bir suret, başıboş bir hayvan ve yolunu kaybetmiş bir varlık olurdu" demiştir.

Bilesin ki edeb iki nevidir: nefsî ve kesbî. Nefsî olan Allah tealanın tevfikinden olandır. Allah onu dilediğine verir ve insanlar ona gıbta ederler. Kesbî ise gayret sarf etmekle (ictihâd), istemekle olur. Hikmet ile elde edilenler ile Arapların lügati buna dâhildir. Bu kısım tüm diyarlarda ve asırlarda övünç kaynağıdır.

Şiir:

Soyu sopu olmayan üdebâyı talep etsin

Kalsa da gitse de ondadır dikkati celbeden

[59b] Dili fesâhat ehli "fazilet, akıl ve edeb iledir, soy ve sop ile değildir" demişlerdir. Kişi, bilgisiyle kişi olur, atalarılyla değil; faziletiyle olur, soy ve sopuyla değil; kemâliyle olur, cemâliyle değil; âdâbıyla olur, esvabıyla değil; aklıyla olur, yakınları ile değil. Bir başkası ise şöyle söylemiştir: "Mahlukat içinde her şeyin bir süsü vardır, kişinin süsü de edebinin tam olmasıdır. Soyu düşük olsa bile kişi, edebi sayesinde bizim aramızda şeref bulabilir." [Bir başkası] şöyle demiştir: "Edeb sahibi kişi, soya ihtiyaç duymaz. Soylular ise edebe muhtaçtırlar. Kendi başına ayakta kalamayan soylu kişiye şaşarım. Ve hayret ederim edeb sahibine ki hasebten müstağni kalır."

Hz. Peygamber'in Necaşî́ye yazdığı [mektup] belagattandır. "İmdi, adetâ biz sana olan güvenimizle senden olduk ve adetâ sen bize olan sevginle bizden biri oldun. Senden çekinmeden istediğimiz her şeyi elde ettik. Korktuğumuz her şeyden de emin olduk." Bir başkası esirin kurtulmasıyla ilgili olarak şöyle söylemiştir: "İmdi, elim kitaptadır, ayaklarım binektedir. Ben sana esmekte olan rüzgardan, kanalında akan sudan daha süratli olarak geliyorum." Me'mûn şöyle söylemiştir: "Ey insanlar, bizim yaptıklarımıza dair bildikleriniz, bizden duyduklarınızdan daha güzelini yapmanıza mani olmasın."

Şiir:

Benim ilmimle amel et, kusurlu olsam da amelimde

Sana ilmim fayda verir, zarar vermez kusurum

Dinleyin bu sözlerimi şayet akl ederseniz

Zira ben kendi yükümden siz kendi yükünüzden sorulacaksınız. 
Büzürcmihr'e şöyle sorulmuştur: "Hangi şey kusuru en fazla setreder. "Akıl" diye cevap vermiş, "peki aklı yoksa demişler", o zaman "şeref (câh)" diye cevap vermiş. "Peki şeref de yoksa demişler. [60a] "Mal" demiş. "Peki malı da yoksa" demişler. "Onun adına söz söyleyen dostlar" demiş. "Bundan da mahrumsa" demişler. "Bu durumda o sezsiz-soluksuz bir şeydir, ona ne bir âmir zarar verir ne de ona [başkasından] bir zarar ulaşır" demiştir.

\section{[2. Fasıl] Zekaya dair fasıl}

Anlatıldığına göre birisine "Rabbin nerededir?" diye sorulmuş, o da cevaben "gözetlemede" demiştir. Zemahşerî şöyle söyler: "İslam milleti üç şey ile övünürse övünç olarak ona yeter: Siyaset için Ömer b. el-Hattâb, zühd için el-Hasen el-Basrî ve belagat için Câhiz." Bir bedeviye lezzetin nelerde olduğu soruldu, "habersiz öpmektedir" diye cevap verdi. Aynı soru hükümdara soruldu, "düşmana karşı zaferdedir" diye cevap verildi. Tacir ise bu soruya "kârdadır" dedi. Alim ise "şüphesinin giderilmesindedir" dedi. Çoban, "verimli bir vadidedir" dedi. Fakir, "ihtiyacın giderilmesindedir" dedi. Muğannî ise "gamı gideren meclistedir". Dedi. Gazi ise "ganimettedir" dedi.

Bir bilgeye "Hangi işlerin cezası daha süratle verilir?" diye soruldu. "Allah'tan başka yardımCISı olmayana yapılan zulmün" diye cevap verdi.

Bir nahiv bilgini, bir vaizin bulunduğu bir minberin yanında oturdu. Vaiz, dil bilgisi hataları yaptı. Nahivci demiş ki "hatalı söyledin". Bunun üzerine vaiz, "Sen rabbine asi oldun. Beni bir dil bilgisi hatasından dolayı nasıl olur da ayıplarsın? Bilmez misin ki niçin fasih konuşmadın diye sorulmaz aksine niçin asi oldun diye sorulur. Eğer durum senin iddia ettiğin gibi olsaydı Harun risalete Musa'dan daha fazla hak sahibi olurdu. Zira Allah teâlâ "ve kardeşim Harun, o benden daha fasih konuşur" buyurmuştur. Hz. Peygamber sallallahu aleyhi ve sellem de "Bir adam bir işte derinlik kesbetmiş olmasın ki rızkında bir noksana düçar kalmış olmasın. Şöyle denilir "Bir konuda iyice derinleşen rızıkta geri kalır." Nitekim şair de şöyle söylemiştir: [60b]

Bir gün gelir dilekçe yazarsan eğer

Talebine vasıl olmayı hedefleyerek

Lafızlarını Arapçaya dökerken dikkat et de

Ehl-i edebin mesleğindenmişsin gibi davranma

\section{Diğer [şiir]}

Zaman aleyhinde işler füzelanın

Hatta adeta onun düşmanı [kendisini] anlayan kişidir

Eğer bilmediğim şeyin cahili olsaydım

Mutlu ederdi beni cehaletim, bildiğim konu nasıl kötü ederse beni

Tıpkı minik bir serçe gibi bahçede nimet içinde yaşayan

Yalnızca Andelib hapsedilir, çünkü terennüm eder o

\section{Diğer [şiir]}

Fazilet ehlininin kapısını çalar, diğer insanların değil

Dünyanın musibet ve afetleri

Tıpkı kuşlar gibi, kafese konmaz onlardan hiç biri

Sesini mutrib kılıp şakıyanları müstesna 
İbnü'l-Mu'tez rahimehullah şöyle buyurmuştur: "Kıraat, tefakkuh ve ulumla iştiğal; kınanmanın, küçük görülmenin, baskı görmenin ve üzüntünün aslıdır." Hasan el-Basrî şöyle söyler: "Nimetin cahile yönelmesini görmen seni cahil olmaya özendirmesin. Nimetin âlime sırtını dönmüş olması da ilmi terketmene sebebiyet vermesin. Zira nimetin cahile yönelmesi infâktır, âlime yönelmesi ise istihkâktır."

Şair şöyle söyler:

Benim bir ihtiyacım var, giderilirse şayet

Nimet içinde, sefa sürerek yaşarım

Ölmüş gitmişlerin hayatını

ve diriltilmelerine bir yol kalmamışların mematını

\section{[3. ] Fasıl: Edebî nüktelere dair}

[Bu nüktelerden] birisi şöyledir: Bir adam aralarında dostluk ilişkisi olan başka bir adama mektup yazar ve ondan bir ihtiyacını gidermesini talep eder. Mektubu bu adama ulaştığında ihtiyacını görür. Bunun sebebi sorulduğunda Ebu't-Tayyib'in [Mütenebbi] şu sözüne işaret etti: "Meşakkat olmasaydı tüm insanlar efendi olurdu."

Bir diğer nükte şöyledir. Bir adam [62a] bir arkadaşına şehre girmekten onu sakındırmak üzere elçi göndermek ister. Zira şehirdeki bir topluluk onu öldürmeyi amaçlamaktadır. Ancak bu mektubunun onların eline geçmesinden korkar ve buna göre bir mektup yazarak mektubunda sözün bir yerinde in edatı şeddeli olacak şekilde "Inne şâe Allah" yazar. Mektup arkadaşına ulaştığında bu kişi Allah teâlânın şu ayetine işaret olduğunu anlar: "[Ve şehrin öbür ucundan bir adam koşarak geldi:] "Ey Musa! (Kavmin) ileri gelenleri mutlaka seni öldürme emrini vermek için konuşuyorlar. [Öyleyse hemen (şehirden) çı.].] O da kendisine mektup gönderene içerisinde in edatı şeddeli olacak şekilde "Innâ şâe Allah" yazan bir cevap gönderir. Mektubu ilk kez gönderen kişi bu ifadeden "onlar orada oldukları müddetçe biz asla oraya girmeyeceğiz" ayetine işaret olduğunu anlar.

Bir diğer nükte şöyledir: Sultan Mahmud vezirleriyle dolaşırken yüzü tüm insanların yüzünden daha güzel olan bir cariye görürler. Sultan, "hayâ, süstür" der. İbn Nuaym ise "Haya, sadeliktir" der. Diğer vezirler hiçbir şey anlamazlar. Daha sonra bu hususu onlara sorduklarında sultan ben "hayâ, süstür" dedim, o ise "Haya, sadeliktir" dedi. Bu nükte, en latif nüktelerdendir. 


\title{
From Good Sense to Good Pleasure: The First Use and Meaning of the Word "Literature"
}

\author{
Berat Açı*
}

\section{Introduction}

As a result of our habits, we approach the words and concepts that we use in our daily lives, as well as the existing phenomena, as if they has been existed from the beginning. Indeed, just like every phenomenon, every word and concept naturally emerges in a certain period of time. Although it is hardly possible to identify the emerging point of some of them, it is relatively possible to identify emerging of others. Efforts to identify the first use of the word "literature" fall into the second group. Efforts to determine when the word was used for the first time within the bounds of possibility are important. The purpose of this article is to initiate a discussion centered on our new findings about when the word was used for the first time in reality (as far as we can).

\section{The Existing Literature on the First Use of the Word Literature}

There is a common belief that the word "literature" was used in the Tanzimat period for the first time. According to Orhan Okay, the literature started to be used as a word and concept in Turkish after the Tanzimat and became increasingly widespread since then (Okay, 1994, p. 395) Okay, who argues that the word "literature" was derived from the word of "edeb" in Arabic, says that such a derivative, which was used in this meaning, had not existed in Arabic until then (1994, p. 395).

Although it goes beyond the limits of this article, we think it is beneficial to convey one of our findings about the first use of the word in Arab language, as it is closely related to the matter. The word "literature" was overtly used as a subtitle called "ve lehu mine'ledebiyyât (literature)" in 11th century scholar Al-Tha'alibi's (d. 1038) "Yatimat al-dahr fi mahasin ahl al-asr," which was a sort of a collection of biographies of poets and litterateurs (Al-Tha'alibi, t.y., vr. 479a). As a result, although the date of the manuscript at our hand is not yet recorded, we offer the first evidence that this word was used in a text of an 11 th century writer.

* $\quad$ Assist. Prof. Dr., İstanbul Şehir University, Department of Turkish Language and Literature.

Correspondence: beratacil@sehir.edu.tr. Address: İstanbul Şehir Üniversitesi Batı Kampusü, Oymacı Sok. No: 15, Altunizade Mah. Üsküdar/İstanbul. 
According to Kaya Bilgegil, who is a leading figure with his competent studies in rhetoric and literature, the word literature is based on a root, which has been used in Arabic since ancient times.

The word "edb" which meant "invitation" in ancient times, gave birth to the word "edeb," which was about elegance and morality a century before Islam. This meaning survived the first years of the Umayyad Caliphate and the last years of the Abbasid Caliphate. Caliphs elected "mueddibs" to raise their children in the last years of the fall of the Umayyad state. We know this turned into a tradition, which was adopted by Abbasid caliphs and their viziers. Mueddibs taught poetry, history and religion. After efforts were made to compile works that would serve for the language, such as grammar, conjugation, prosody and rhetorical style, they were also explained with the word "edeb" which maintained this concept scope until the last century (1989, p. 2).

This word was used in a meaning that was close to its current meaning in the second half of the 19th century. According to Okay, it meant, "The literature is an art of the verbalization of emotions, thoughts and dreams in a way that will arouse excitement, admiration and aesthetic pleasure in readers" $(1994,396)$. Other researchers suggest that the word started to be used to meet the French word of "litterature," that had a similar meaning. For instance, Kazım Yetiş argues, "We see that the word achieved a widespread use in Namık Kemal['s works]. His first piece that includes his ideas about 'literature' and 'Ottoman literature' is titled 'Includes Considerations about the Literature of the Ottoman Language'. Here, the word literature is continuously used as an individual term" (Yetiş, 1996, p. 144).

Recaizade Mahmud Ekrem and Kemalpashazade are two intellectuals of the time, who were both willing to and hesitant about using the word with its new meaning. Fatih Altuğ says, "Looking closely it is apparent that, Kemalpashazade Said says he will use the phrase of poetry and composition on the one hand, he accepts that this phrase was replaced by literature on the other" $(2007$, p. 20). So, he expresses the hesitations of the intelligentsia and intellectuals confronting the new situation. It is obvious that although the word "literature" was in use in the 1880s, there was not an agreement over its meaning and what it would replace. Moreover, it is clear that there is a relation between the word "literature" and French word of "litterature" which meant literary composition. But, they did not want to exclude poetry. So, they were not more useful than Ziya Pasha's preference for Poetry and Composition.

\section{The First Use and Meaning of the Word Literature}

According to our existing knowledge, the word "literature" was firstly used in Hüseyin b. Hasan al-Kostantinî's Arabic work called Lataif al-afkar va Kashif al-asrar in the Ottoman period. Al-Kostantinî, who was one of the kadis of the time of Suleiman the Magnificent, presented his work to Ibrahim Pasha, who served as the grand vizier between 1523 and 1526. Lataif al-afkar va Kashif al-asrar was written in an encyclopedic style. Hüseyin Yılmaz argues that the work was written in this style to train Ibrahim Pasha in the topics of "management, morals, history, literature and religious traditions" as he became the grand vizier at a early age that is $29(2005$, p. 68$)$. The significance of the work for this article, literature and the history of literature is that one of its five chapters bears the title of "literature." The chapters of the book which consists of five chapters and 65 sub-sections are as follows: 
a) "Politics," b) "The history of caliphs in the Two Holy Mosques from Adam to 935," c) "Literature," d) "Praised and reviled habits, e) "About the oddities of creatures and assets" (Özgür Kavak, 2012, p. 97) According to Kavak, the work completed in is 935/1529 (2012, p. 96) and it has three copies. Kavak examined the oldest copy (1031/1622) and the other two copies do not include a chapter on literature. $(2012$, p. 95).

The third section of the book, which bears the main heading of Literature consists of three sub-sections as follows: (1) About literature and the praise of good sense (akl-ı selim) and superior minds, (2) About intelligence, (3) About literary wits. We will try to achieve a holistic picture by addressing each chapter separately in this part of the article.

As understood from the title of the first chapter, literature was used together with akl-I selim, which is the ability of understanding quickly. It seems that the writer thought "literature" along with "statement" (beyan) in his mind. This is because the first concept that the writer resorts to explain literature, perhaps, emerged as the first pillar of literature. As it is known, beyan is one of the three parts of the classical science of rhetoric along with ma'ânî and bedî' (Hâşimî, 1971, p. 153-215; el-Cârim-Emîn, 1981, p. 19-127). "As a literary term, beyan means a science which brings the needed natural faculty of elucidating the meaning in wording and examines styles and rules of expressing emotions and thoughts in different ways" (Hacımüftüoğlu, 1992, p. 22). The writer used the word "beyan" which is cited in the first four verses of the Surah Ar-Rahman - the 55th surah in Quran -as a double-entendre. The first meaning of it is "to explain" and the second is the rhetorical meaning that we mentioned above. Just after that, it is conveyed that Prophet Mohamed said that at least one part of the beyan is magical.

Al-Kostantinî quotes one of Hisham b. Urve's (d. 763) statements about fesahat (fluency) and beyan while giving examples about beyan, "Fesahat and beyan are the most interesting things for me among the things that people deal with" (1622, vr. 59a). What is new here is that the writer added fesahat to beyan. Fesahat is a rhetorical term like beyan. Although beyan concerns meaning and expression mostly, fesahat is about statements. As a term of rhetoric, it means the "perfection and clarity of statements" (Çuhadar, 1995, p. 423). The next two citations are about "speech" and "language."

It is seen that a person's ability of speaking and being addressed are highlighted in this part. Wanting to ensure this, the writer divides literature into two after mentioning rhetoric, beyan, fesahat, speech and language. Here, he uses the word "edeb" which has been used in the meaning of literature in Arabic so far. So, it is proper to say that the writer could not make a clear distinction between the words of edeb and literature in his mind.

According to the writer, edeb is divided into two: nefsî (self/given) and kesbî (acquired). As nefsî means the achievement of Allah's help, Allah gives it to person whom he wants. According to this definition, nefsî edeb is similar to the distinction between innate and acquired poets (Latifi, 2000, p. 485). As mentioned above, fesahat is a part of literature. According to people who have fesahat, in other words, who have eloquence, virtue cannot be obtained through family, but through reason and edeb.

Consequently, this part explains literature within a range that consists of akl-ı selim, beyan, fesahat, speech, language, rhetoric and edeb. After all, a connection is established between 
all of these elements and reason, and it is emphasized that an individual can be honorable through his reason even if he does not have a lineage. So, it can be suggested that although nefsî edeb is not an innate talent, literature is a quality, which can be obtained through reason.

The second chapter is dedicated to intelligence after issues about literature, rhetoric and reason. The writer quotes a sentence from al-Zamakhshari (d. 1144) who is a famous Islamic scholar: "Praising with three people is enough for Muslims: Umar Son of Al-Khattab in politics, Hasan of Basra in asceticism and al-Jahiz in rhetoric" (el-Kostantinî, 1622, vr. 60a). We think this order is important for the entirety of the book, as the book that was presented to Ibrahim Pasha can be considered as a political treatise. These three figures are pointed as role models for Ibrahim Pasha and other readers. It advised a statesman to try to have Umar's politics, Hasan's asceticism-based Sufi perspective and al-Jahiz's eloquent pleasure of language.

The final chapter of the chapter on Literature is about literary wits. As it is, the lexical meaning of the wit is "a pleasurable and thought-provoking word as it bears a witty meaning and is a work of intelligence." Therefore, wit is directly related to both fesahat and intelligence. It is necessary to have a quick wit and strong accumulation of knowledge to understand the subtleties in wits. So wits become a tool that measures the addressee's relation with literature.

To sum up, the section about literature consists of three chapters: (1) Akl-ı selim and superior minds, (2) Intelligence, and (3) Literary wits. When the three chapters are considered together, it is seen that reason and intelligence stand out as common materials.

\section{Conclusion}

It is a common belief in academy that the word "literature" started to be used for the first time in the second half of the 19th century. Accordingly, it was derived as a philological and academic word to meet the French word of "litterature" in the second half of the 19th century and to fulfill the area of "Poetry and Composition" which was previously named as verse and prose. Although there are studies about the conceptualization process of the word, which gained its current meaning over the course of time, there is not a major critical approach toward its existence in the past.

Lataif al-afkar va Kashif al-asrar, which was written in the first half of the 16th century, offers some data that urges us to profoundly re-question our ideas about the issue. It was written as a political treatise and offered to Pargalı Ibrahim Pasha in 1529. The work has three copies; the oldest one of which dated to 1622. The significance of this work for our topic is that one of its five chapters is about literature. The part that we translated above is of critical importance, in terms of the meaning that it gives to literature, and its early use of the word "literature". As a result of our examinations, we have found in this part that the word "literature" is used in a meaning that is composed of akl-ı selim, intelligence, the beyan and fesahat parts of rhetoric, historic anecdotes, morals, religion and literary wits.

Consequently, debates and research about the word "literature" reveal the difficulty of saying a final word about any scientific issue. As we did here, contenting with the date that we reached about the first emergence of a phenomenon or word becomes an academic necessity. 


\section{Kaynakça / References}

Altuğ, F. (2007). Modernity and Subjectivity in the Literary Criticism of Namık Kemal (Doktora Tezi, Boğaziçi Üniversitesi). İstanbul.

Bilgegil, M. K. (1989). Edebiyat Bilgi ve Teorileri (Belâgât). İstanbul: Enderun Kitabevi.

Çuhadar, M. (1995). Fesahat. TDV İslam Ansiklopedisi içinde (c. 12, s. 423-424). İstanbul: TDV Yayınları.

el-Cârim, Alî ve Mustafâ Emîn. (1981). El-Belâgatü'l-Vâzıha (s. 19-127). (t.y.). Dârü'l-Âfâki'l-Bedîde.

el-Kostantinî, H. b. H. (1622). Letâifü'l-efkâr ve Kâşifü'l-esrâr. Süleymaniye Kütüphanesi, Reisülküttâb, No: 698.

Hacımüftüoğlu, N. (1992). Beyân. TDV İslam Ansiklopedisi, içinde (c. 6, s. 22-23). İstanbul: TDV Yayınları. Hâşîmî, S. A. (1971). Cevâhirü'l-Belâga. Beyrut: Dârü'I-Kütübi'l-IImiyye.

Kandemir, M. Y. (1998). Hişâm b. Urve. TDV İslam Ansiklopedisi içinde (c. 18, s. 155-156). İstanbul: TDV Yayınları.

Karakoç, K. İ. (2012). Ulus-Devletleşme Süreci ve "Türk' Edebiyatı"nın İnşası (1923-1950) (Doktora Tezi, İhsan Doğramacı Bilkent Üniversitesi). Ankara.

Kavak, Ö. (2012). Bir Osmanlı Kadısının Gözüyle Siyaset: Letâifü'l-efkâr ve Kâşifü'l-esrâr Yahut Osmanlı Saltanatını Fıkıh Diliyle Temellendirmek. M.Ü. Ilahiyat Fakültesi Dergisi 42, 95-120.

Kavak, Ö. (2014, 11 Ocak). Saltanatı Fıkıh Diliyle Temellendirmek: Letâifü'l-efkâr ve Kâşifü'l-esrâr. İstanbul: Bilim ve Sanat Vakfı.

Latîfî. (2000). Tezkiretü'ş-Şuârâ ve Tabsıratü'n-Nuzemâ (R. Canım, Hzl.). Ankara: Atatürk Kültür Merkezi Yayını.

Literature. (t.y.) http://www.etymonline.com/index.php?allowed_in_frame=0\&search=literature adresinden 15 Ocak 2016 tarihinde edinilmiştir.

Parlatır, İ. vd. (Hzl.) (1998). Nükte. Büyük Türkçe Sözlük içinde (s. 1665). Ankara: TDK Yayınları.

Okay, M. O. (1994). Edebiyat. TDV İslam Ansiklopedisi içinde (c. 10, s. 395-397). İstanbul: TDV Yayınları.

Öztürk, M. ve Mertoğlu, M. S. (2013). Zemahşerî. TDV İslam Ansiklopedisi içinde (c. 44, s. 235-238). İstanbul: TDV Yayınları.

Sealibî, E. M. (t.y.). Yetîmetü'd-dehr fî mehâsini ehli'l-asr. Süleymaniye Kütüphanesi, Nuruosmaniye, no: 4375.

Sealibî, E. M. (1729-30). Yetîmetü'd-dehr fî mehâsini ehli'l-asr. Süleymaniye Kütüphanesi, Ragıp Paşa, no: 1222.

Serdaroğlu, V. (2008). Edeb der Edebiyat. DEM Dergi 1(4), 24-29.

Şeşen, R. (1993). Câhiz. TDV İslam Ansiklopedisi içinde (c. 7, s. 20-24). İstanbul: TDV Yayınları.

Tietze, A. (2002). Tarihi ve Etimolojik Türkiye Türkçesi Lugatı (c. 1, [A-E]). İstanbul: Simurg.

Topuzoğlu, T. R. (2009). Sealibî, Ebû Mansûr. TDV İslam Ansiklopedisi içinde (c. 36, s. 236-239). İstanbul: TDV Yayınları.

Yetiş, K. (1996). Talîm-i Edebiyat'ın Retorik ve Edebiyat Nazariyâtı Sâhasına Getirdiği Yenilikler. Ankara: Atatürk Kültür Merkezi Yayını.

Yılmaz, H. (2005). The Sultan and the Sultanate: Envisioning Rulership in the Age of Süleymân the Lawgiver (1520-1566) (Doktora Tezi, Harvard University). Massachusetts. 